\title{
Antagonistic Roles of P2X7 and P2Y2 Receptors in Neurodegenerative Diseases
}

\author{
Talita Glaser, Ágatha Oliveira-Giacomelli, Lyvia Lintzmaier Petiz, Deidiane Elisa Ribeiro, \\ Roberta Andrejew and Henning Ulrich*
}

Department of Biochemistry, Institute of Chemistry, University of São Paulo, São Paulo, Brazil

Keywords: motor disease, cognitive decline, neuroinflammation, ATP, UTP, neurogenesis, brain degeneration, brain repair, microglia

\section{INTRODUCTION}

Purinergic signaling participates in physiological and pathophysiological processes in the developing and adult brain. Here, we discuss the state of the art of developments in P2 adenosine (ATP) and uridine (UTP) triphosphate activated purinergic receptor research and subsequent applications for the better understanding of the participation of purinergic signaling in neurodegeneration and neuroprotection.

In a seminal review in 2008, Burnstock (2008) already defined the most important features of purinergic P2 receptors in neurodegeneration, defining their roles in brain tissue damage by excessive extracellular ATP release, induction of neuroinflammation and interference in neural regeneration processes (scar formation, neuronal sprouting and adult neurogenesis). Professor Burnstock cited in this regard cerebral ischemia, Parkinson's (PD), Alzheimer's (AD) and Huntington's (HD) diseases and concluded that hyper-expression and hyperactivities of some purinergic P2 receptors would be disease worsening, such as P2X7 receptors (P2X7R).

Neuroinflammation is strongly related to P2X7R activation, since danger associated molecular patterns (DAMPs), including extracellular ATP, are released (Ribeiro et al., 2020). Hence, ATPinduced activation of $\mathrm{P} 2 \mathrm{X} 7 \mathrm{R}$ prompts downstream release of proinflammatory mediators, such as interleukin $1 \beta$ (IL-1 $\beta$ ), through the assembling of the NLRP3 inflammasome (Bartlett et al., 2014). Thus, the NLRP inflammasome is followed by a downstream pro-apoptotic signaling cascade involved in neurodegenerative diseases (Heneka et al., 2010). Neuroinflammation involves the activation of microglia and astrocytes (Beamer et al., 2016), and the P2X7R can be found at highest density in the microglia (Weisman et al., 2012b). Its hyper-activation promotes the over-release of neurotransmitters from neuronal presynaptic terminals, contributing to apoptosis (Sperlágh and Illes, 2014). Further, we have shown that P2X7R are important inhibitors for neural phenotype determination using mouse pluripotent stem cells (Glaser et al., 2014; Glaser et al., 2020b), and promotion of glial differentiation (Yuahasi et al., 2012), aggravating tissue repair.

Inducing endogenous neurogenesis or implanting in vitro obtained neurons or their precursors are promising strategies for neurodegeneration prevention or neuronal recovery. Our laboratory has been contributing to the field of neurogenesis by detailed investigation of P2 receptor subtype expression and activity pattern along the course of neural differentiation (reviewed by Burnstock and

Glaser T, Oliveira-Giacomelli Petiz LL, Ribeiro DE, Andrejew $R$ and Ulrich $H$ (2021) Antagonistic Roles of P2X7 and P2Y2 Receptors in Neurodegenerative Diseases. Front. Pharmacol. 12:659097. doi: 10.3389/fphar.2021.659097 
Ulrich, 2011). Correspondingly, we clarified the neuroprotective features exerted by P2Y2 receptors (P2Y2R) during neural progenitor differentiation (Resende et al., 2008; Ulrich et al., 2012).

The P2Y2R is a $\mathrm{G}_{\mathrm{q}}$-coupled receptor sensitive to activation by ATP and UTP/UDP, interacting with integrins and growth factor receptors (Weisman et al., 2012a) as well as inducing neuronal differentiation through activation of NGF/TrkA signaling, as shown for PC12 cells. Thus, this receptor can also promote proliferation of glioma C6 cells through the Ras-ERK pathway (Homolya et al., 1999; Arthur et al., 2005; Franke and Illes, 2006). Recently we demonstrated P2Y2R roles in favoring GABAergic phenotype determination (Glaser et al., 2020b). In addition, a novel concept in the neurodegeneration field characterizes the $\mathrm{P} 2 \mathrm{X} 7 \mathrm{R}$ as a trigger of pro-inflammatory responses, while the $\mathrm{P} 2 \mathrm{Y} 2 \mathrm{R}$ has neuroprotective properties. In this opinion article, we compare the role of both receptors in different neurodegenerative diseases we are working on.

\section{BALANCE OF P2Y2R AND P2X7R IN MOTOR SYSTEM-RELATED DISEASES}

In a previous review article, we discussed the intercorrelation between two basal ganglia disorders that compromise the motor system, HD and PD (Oliveira-Giacomelli et al., 2018; Glaser et al., 2020a). Reinforcing this idea, administration of the P2X7R antagonist Brilliant Blue G (BBG) could restore dyskinesia, a common symptom between both diseases (Fonteles et al., 2020).

\section{Huntington's Disease}

$\mathrm{HD}$ is a genetic degenerative and fatal disorder characterized by the loss of GABAergic neurons in the basal ganglia in the earlier stages, and extensive cortex degeneration later on, causing motor, cognitive and psychiatric dysfunctions. The mutation causing the disease consists of an expansion of repeated CAG triplets in the huntingtin gene (HTT), encoding for an expanded polyglutamine (polyQ) stretch.

Some previous works using mutant huntingtin expressing neurons or HD transgenic mouse models demonstrated roles for P2X7R in HD pathophysiology (Díaz-Hernández et al., 2009). In vitro, elevated levels of $\mathrm{P} 2 \mathrm{X} 7 \mathrm{R}$ and $\mathrm{P} 2 \mathrm{X} 7 \mathrm{R}$-mediated calcium influx in soma and terminals of $\mathrm{HD}$ neurons increased susceptibility to apoptosis. In vivo administration of the P2X7R-antagonist BBG to a HD mouse model prevented neuronal apoptosis and attenuated body weight loss and motor-coordination deficits. In the last year, a study using postmortem striatum of $\mathrm{HD}$ patients corroborated the previous animal data. In both studies, the full-length form of the P2X7R protein and the naturally occurring trunked $\mathrm{C}$-terminus region variant, showed upregulated expression levels. Taken together, P2X7R activity is prejudicial to brains of HD subjects.

In a recent work, we showed that neural precursor cells derived from embryonic stem cells regulate spontaneous calcium oscillations that control the translocation of phosphorylated
CREB into the nucleus, activating the ASCL-1 pro-neuronal gene, thereby favoring neurogenesis towards the GABAergic phenotype (Glaser et al., 2020b). Consistently, our data from human neural precursor cells derived from induced pluripotent stem cells of $\mathrm{HD}$ subjects demonstrated impaired P2Y2Rmediated intracellular calcium mobilization and absent calcium spontaneous oscillations related to ASCL-1 activation (Glaser et al., 2020b).

\section{Parkinson's Disease}

$\mathrm{PD}$ is a motor disorder caused by the degeneration of the substantia nigra, thereby decreasing the amount of released dopamine in the basal ganglia. Due to intense neuroinflammation, mitochondrial dysfunction and neuronal degeneration of PD, the P2X7R has been extensively studied. $\mathrm{PD}$ patients exhibit the $1513 \mathrm{~A} \rightarrow \mathrm{C}$ single nucleotide polymorphism in the $\mathrm{P} 2 \mathrm{X} 7 \mathrm{R}$ gene, which induces loss-offunction ( $\mathrm{Gu}$ et al., 2001) and elevated risks of sporadic/lateonset PD development (Liu et al., 2013). In the striatal 6hydroxydopamine (6-OHDA) lesion, increased binding of radioligands to the $\mathrm{P} 2 \mathrm{X} 7 \mathrm{R}$ was found in the striatum and substantia nigra of rodents (Crabbé et al., 2019). Corroborating these results, P2X7R gene expression was gradually increased within 5 weeks after forebrain bundle lesion by 6-OHDA in rats (Oliveira-Giacomelli et al., 2019).

Antagonism of P2X7R demonstrated promising results. 6OHDA-injured rats treated with BBG restored dopaminergic fibers in the striatum and dopaminergic neurons in the substantia nigra (Ferrazoli et al., 2017; Oliveira-Giacomelli et al., 2019). Importantly, P2X7R blockade prevented motor impairment, mitochondrial dysfunction and dopamine deficit as well as decreased pro-apoptotic regulator expression and micro/astrogliosis induced by 6-OHDA (Marcellino et al., 2010; Carmo et al., 2014; Kumar et al., 2017; Oliveira-Giacomelli et al., 2019). BBG also alleviated dyskinesia, the aberrant balance between D1 and D2 receptors expression and micro/astrogliosis associated with L-DOPA treatment, the current gold standard treatment for PD (Fonteles et al., 2020).

In vitro, $\alpha$-synuclein induced P2X7R activation in SH-SY5Yderived dopaminergic neurons that modulated mitochondrial dysfunction, ATP release, recruitment of pannexin-1 and decreased ATP degradation, with consequent cell death (Wilkaniec et al., 2017, Wilkaniec et al., 2020).

\section{Preventing and Recovering Basal Ganglia Lesions}

As we highlighted here, strong evidence points at the P2X7R as a neurodegeneration inducer for both $\mathrm{PD}$ and $\mathrm{HD}$ through neuroinflammation. Pharmacological tools, such as blockade of the P2X7R over activation by BBG, may prevent the further damage. We believe that endogenous neurogenesis inducers, such as the P2Y2R, may add therapeutic strength by promoting the delivery of newly born neurons from the subventricular zone to the site of degeneration and recovering the lesioned striatum and movement control. 


\section{BALANCE OF P2Y2R AND P2X7R IN COGNITIVE-RELATED DISEASES}

Both $\mathrm{AD}$ and epileptic seizures impair cognition and steadily damage hippocampal circuitry, leading to progressive memory loss. Neuronal hyperexcitability induced by seizures amplifies the synaptic release of the main component of senile plaques found in the brain of $\mathrm{AD}$ patients, such as beta amyloid peptide $(\mathrm{A} \beta)$, enhancing cell death and cognitive decline. Nowadays, strong evidence indicates epilepsy as a comorbidity of $\mathrm{AD}$, which is corroborated by P2X7R and P2Y2R functions in these brain disorders (Noebels, 2011).

\section{Alzheimer's Disease}

$\mathrm{P} 2 \mathrm{X} 7 \mathrm{R}$ expression is upregulated in $\mathrm{AD}$ patients and animal models (Parvathenani et al., 2003; McLarnon et al., 2006; Ryu and McLarnon, 2008). Receptor expression augments in microglia surrounding $A \beta$ plaques, occurring in parallel with $\mathrm{AD}$ progression (Lee et al., 2011). A $\beta$ aggregation triggers neuroinflammation in $\mathrm{AD}$, as patients may have $\mathrm{A} \beta$ deposits as early as 10 years prior to first AD symptoms (Vermunt et al., 2019). Upon ATP binding, the P2X7R activates microglia, leading to a proinflammatory state that can promote amyloid-precursor protein (APP) release and oxidative stress in $\mathrm{AD}$ pathology, leading to synaptic dysfunction/loss and cell death.

In SH-SY5Y neuroblastoma cells, BzATP stimulated the release of APP, and the use of antagonists or knockdown with siRNA confirmed P2X7R dependence of APP release (Delarasse et al., 2011). AD animal models showed that the $\mathrm{P} 2 \mathrm{X} 7 \mathrm{R}$ function is as necessary for $\mathrm{A} \beta$ deposition. The treatment with P2X7R antagonists decreased the size and number of 8 months old J20 mice hippocampal amyloid plaques (DiazHernandez et al., 2012), while 10 months old P2X7R knock-out APP/PS1 mice displayed less A $\beta$ lesions, improved cognitive deficits and synaptic plasticity (Martin et al., 2019). A $\beta$ plaques promoted the release of IL-1 $\beta$, an event depending on P2X7R activation (Sanz et al., 2009). This occurred at least in part through $\mathrm{A} \beta$-induced generation of pore-like structures, allowing ATP leakage into extracellular environments and binding to P2X7R, enhancing excitatory synaptic activity (Sáez-Orellana et al., 2016). The inflammatory process resulting from hyperexcitability is one of the key factors in $\mathrm{AD}$ (Busche and Konnerth, 2015). Lastly, high levels of reactive oxygen species (ROS) are commonly detected in postmortem brains of $\mathrm{AD}$ patients (Tönnies and Trushina, 2017). P2X7R activation is associated with $\mathrm{A} \beta$-induced microglial $\mathrm{H}_{2} \mathrm{O}_{2}$ release through NADPH oxidase activation (Soo et al., 2007). P2X7R-positive microglial cells located around $A \beta$ plaques expressed the catalytic NADPH subunit, and P2X7R upregulation combined to ROS release was associated to $A \beta$ deposition increase and synaptotoxicity in AD (Lee et al., 2011).

Adversely, in vitro and in vivo studies corroborate neuroprotective roles of $\mathrm{P} 2 \mathrm{Y} 2 \mathrm{R}$ activation in AD. Postmortem studies showed that P2Y2R immunoreactivity is preserved in the occipital cortex (minimally affected region) while it is reduced in the parietal cortex (highly affected region) of $\mathrm{AD}$ patients. Interestingly, decreased expression of $\mathrm{P} 2 \mathrm{Y} 2 \mathrm{R}$ in the parietal cortex is correlated with $\mathrm{AD}$ neuropathologic scores and markers of synapse loss (Lai et al., 2008).

In human $1321 \mathrm{~N} 1$ astrocytoma cells, P2Y2R stimulation enhanced non-amyloidogenic processing of APP. Corroborating these results, $\mathrm{P} 2 \mathrm{Y} 2 \mathrm{R}$ activation in rat primary cortical neurons treated with IL- $1 \beta$ enhanced the release of $\alpha$-amyloid protein (Kong et al., 2009). In addition, treatment with P2Y2R agonists (ATP and UTP) enhanced the uptake and degradation of $A \beta$, while $A \beta$ application increased $P 2 Y 2 R$ gene expression in mouse primary microglial cells (Kim et al., 2012). The role of P2Y2R has also been investigated in transgenic mice bearing human APP with Swedish and Indiana mutations, an animal model of AD. In these animals, haploinsufficiency of P2Y2R augmented plaque formation and enhanced $A \beta$ levels in the cerebral cortex and hippocampus as well as led to neurological deficits within 10 weeks (Ajit et al., 2014). Moreover, P2Y2R deletion induced premature death in these transgenic mice (Ajit et al., 2014).

\section{Epilepsy}

Epilepsy can impact cognitive function, since the seizures cause excitotoxicity and cell death (Helmstaedter, 2013). Similarly to AD, $\mathrm{P} 2 \mathrm{X} 7 \mathrm{R}$ protein levels are upregulated in regions damaged by seizures and in the hippocampus of animal models. As previously summarized (Engel et al., 2012; Engel et al., 2016), the lack of the P2X7R promotes susceptibility to status epilepticus, while P2X7R antagonists are potent anticonvulsants (Engel et al., 2012; Engel et al., 2016; Beamer et al., 2017; Zeng et al., 2017; Burnstock and Knight, 2018; Song et al., 2019; Doğan et al., 2020; Hong et al., 2020; Morgan et al., 2020). P2Y2R knockout animals present higher glutamate release in the hippocampus (Alhowail et al., 2020), and uridine triphosphate administration had sleep-promoting and anti-epileptic actions, improved memory function and affected neuronal plasticity (Dobolyi et al., 2011; Alves et al., 2017).

\section{Preventing and Restoring Cognition}

Both $\mathrm{AD}$ and Epilepsy harm cognition capabilities, mainly through microglial activity, thus damaging the hippocampus. P2X7R sensitization promotes the accumulation of plaques, while P2Y2R activity enhances their uptake and degradation. In this case, we have two major players, the good and the evil, one stimulated by ATP and the other by UTP, like a Yin Yang effect.

\section{DISCUSSION AND PERSPECTIVES}

Pharmacological intervention of purinergic signaling provides promising therapeutic avenues. We focused in this Opinion article on beneficial and harmful actions of purinergic receptors, affecting neuroinflammation and neuronal repair (Figure 1). In this scenario, two main players have been identified: 1) The P2X7R, known to counteract neuronal differentiation during development, which supposedly has similar effects on adult neurogenesis and also limits the available neural stem cell pool (Oliveira et al., 2016). This receptor is also directly connected to ATP induced inflammasome activation, mediating sterile inflammation of 


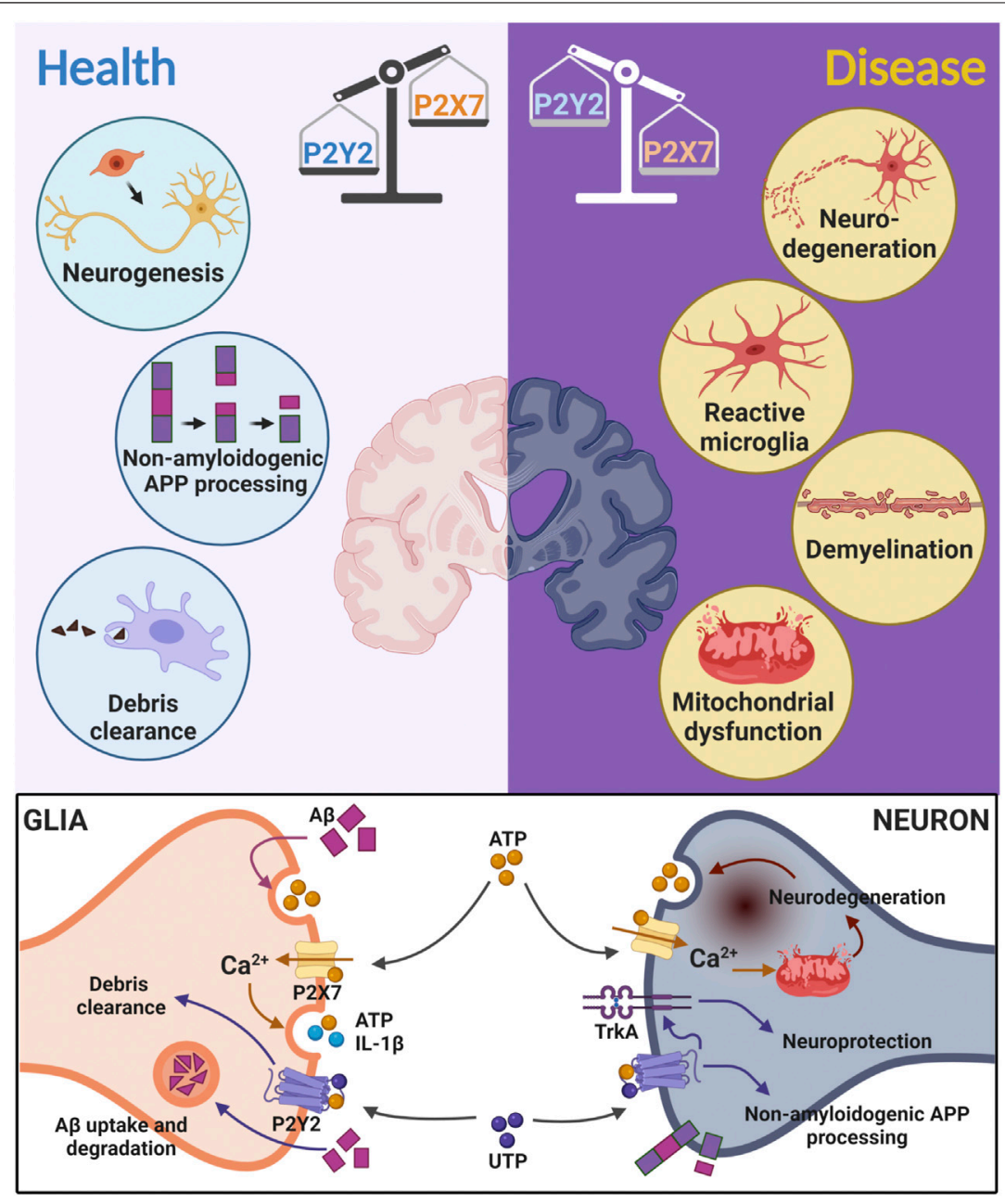

FIGURE 1 | The yin and yang effects of P2Y2R and P2X7R activities. A thin balance between P2Y2R and P2X7R activities is required to maintain a healthy communication between neural cells. Increased P2Y2R activation (Health-left) induces neuroprotective effects, like neurogenesis, clearance of debris from apoptotic cells and amyloid precursor protein (APP) non-amyloidogenic processing in Alzheimer's Disease. P2X7R expression and activity is augmented in the diseased brain (Disease-right), inducing neurodegeneration, microglia activation, demyelination, and mitochondrial dysfunction. At the cellular level, ATP is intensely released during neurodegeneration. Released ATP by activating P2X7R increases intracellular $\mathrm{Ca}^{2+}$ levels and can induce detrimental effects such as mitochondrial dysfunction and neurodegeneration. In glial cells, P2X7R activation induces the release of more ATP and interleukins, such as IL-1 $\beta$. ATP and UTP can bind to P2Y2R inducing neuroprotective effects, including: debris clearance by glial phagocytosis; increase in the sensibility of TrkA receptors and stimulation of the neural growth factor pathway; amyloid- $\beta$ (A $\beta$ ) uptake and degradation as well as non-amyloidogenic APP processing (in Alzheimer's Disease). Increased ATP release can also be triggered by A $\beta$ exposure. Created with BioRender.com.

the brain; 2) The P2Y2R, shown to promote neuronal differentiation and neuronal phenotype determination of stem cells, has been associated with neuroprotective features in various brain disorders, including $\mathrm{AD}, \mathrm{HD}$ as well as in epilepsy. The $\mathrm{P} 2 \mathrm{Y} 2 \mathrm{R}$ is highly expressed in axonal projections in the striatum and substantia nigra (Amadio et al., 2007) as well as in microglia, mediating the uptake of toxic peptides such as $A \beta$ (Kim et al., 2012). In this sense, we hypothesize that the P2Y2R participates in the phagocytic process of $\alpha$-synuclein in PD. However, the $\mathrm{P} 2 \mathrm{Y} 2 \mathrm{R}$ is unexplored in the $\mathrm{PD}$ pathogenesis, evidencing a gap in the literature and a promising target for future research. IL-1 $\beta$ induces P2Y2 receptor expression (Peterson et al., 2013); thereby, we propose that $\mathrm{P} 2 \mathrm{Y} 2 \mathrm{R}$ activity acts as an effort to restore brain homeostasis.
Several BBB-permeant small molecule P2X7R antagonists were developed (for a review, see Andrejew et al., 2020), and some of them are undergoing clinical trials for the treatment of neurodegeneration: CE22,535, already tested in phase 2 and 3 clinical trials; and JNJ541754467 tested in a phase 1 clinical trial (for a detailed review, see Calzaferri et al., 2020). Therapeutic P2Y2R agonists include diquafosol (Lau et al., 2014) and Denufosol tetrasodium (Deterding et al., 2007). However, BBB-permeant P2Y2R activators need yet to be developed. P2X7R antagonists and P2Y2R agonists could be administered alone or in combination with conventional drug therapy. An interesting pharmacological approach would be based in the combination of P2X7R antagonist and P2Y2R agonist. 


\section{AUTHOR CONTRIBUTIONS}

TG, ÁO-G, LP, DR, and RA wrote the article and prepared the figure. HU conceived the study and contributed to writing of the manuscript. All authors contributed to the article and approved the submitted version.

\section{FUNDING}

HU acknowledges grant support from the São Paulo Research Foundation (FAPESP, Project Nos. 2018/07366-4 and 2018/ 08426-0). HU acknowledges the National Council for Scientific and Technological Development for fellowship support (CNPq,

\section{REFERENCES}

Ajit, D., Woods, L. T., Camden, J. M., Thebeau, C. N., El-Sayed, F. G., Greeson, G. W., et al. (2014). Loss of P2Y2 nucleotide receptors enhances early pathology in the TgCRND8 mouse model of Alzheimer's disease. Mol. Neurobiol. 49, 1031. doi:10.1007/s12035-013-8577-5

Alhowail, A., Zhang, L. X., Buabeid, M., Shen, J. Z., and Suppiramaniam, V. (2020). Role of the purinergic P2Y2 receptor in hippocampal function in mice. Eur. Rev. Med. Pharmacol. Sci. 24, 11858-11864. doi:10.26355/eurrev_202011_23843

Alves, M., Gomez-Villafuertes, R., Delanty, N., Farrell, M. A., O’Brien, D. F., MirasPortugal, M. T., et al. (2017). Expression and function of the metabotropic purinergic P2Y receptor family in experimental seizure models and patients with drug-refractory epilepsy. Epilepsia 58, 1603-1614. doi:10.1111/epi.13850

Amadio, S., Montilli, C., Picconi, B., Calabresi, P., and Volonté, C. (2007). Mapping $\mathrm{P} 2 \mathrm{X}$ and $\mathrm{P} 2 \mathrm{Y}$ receptor proteins in striatum and substantia nigra: an immunohistological study. Purinergic Signal. 3, 389-398. doi:10.1007/ s11302-007-9069-8

Andrejew, R., Oliveira-Giacomelli, Á., Ribeiro, D. E., Glaser, T., Arnaud-Sampaio, V. F., Lameu, C., et al. (2020). The P2X7 receptor: central hub of brain diseases. Front. Mol. Neurosci. 13, 124. doi:10.3389/fnmol.2020.00124

Arthur, D. B., Akassoglou, K., and Insel, P. A. (2005). P2Y2 receptor activates nerve growth factor/TrkA signaling to enhance neuronal differentiation. Proc. Natl. Acad. Sci. 102, 19138-19143. doi:10.1073/pnas.0505913102

Bartlett, R., Stokes, L., and Sluyter, R. (2014). The P2X7 receptor channel: recent developments and the use of $\mathrm{P} 2 \mathrm{X} 7$ antagonists in models of disease. Pharmacol. Rev. 66, 638-675. doi:10.1124/pr.113.008003

Beamer, E., Fischer, W., and Engel, T. (2017). The ATP-gated P2X7 receptor as a target for the treatment of drug-resistant epilepsy. Front. Neurosci. 11, 21. doi:10.3389/fnins.2017.00021

Beamer, E., Gölöncsér, F., Horváth, G., Bekő, K., Otrokocsi, L., Koványi, B., et al. (2016). Purinergic mechanisms in neuroinflammation: an update from molecules to behavior. Neuropharmacology 104, 94-104. doi:10.1016/j. neuropharm.2015.09.019

Burnstock, G. (2008). Purinergic signalling and disorders of the central nervous system. Nat. Rev. Drug Discov. 7, 575-590. doi:10.1038/nrd2605

Burnstock, G., and Knight, G. E. (2018). The potential of P2X7 receptors as a therapeutic target, including inflammation and tumour progression. Purinergic Signal. 14, 1. doi:10.1007/s11302-017-9593-0

Burnstock, G., and Ulrich, H. (2011). Purinergic signaling in embryonic and stem cell development. Cell. Mol. Life Sci. 68, 1369-1394. doi:10.1007/s00018-0100614-1

Busche, M. A., and Konnerth, A. (2015). Neuronal hyperactivity-a key defect in Alzheimer's disease? BioEssays 37, 624-632. doi:10.1002/bies.201500004

Calzaferri, F., Ruiz-Ruiz, C., Diego, A. M. G., Pascual, R., Méndez-López, I., CanoAbad, M. F., et al. (2020). The purinergic P2X7 receptor as a potential drug target to combat neuroinflammation in neurodegenerative diseases. Med. Res. Rev. 40, 2427-2465. doi:10.1002/med.21710

Carmo, M. R. S., Menezes, A. P. F., Nunes, A. C. L., Pliássova, A., Rolo, A. P., Palmeira, C. M., et al. (2014). The P2X7 receptor antagonist Brilliant Blue G
Project No. 306392/2017-8). DR, AO-G, and TG are grateful for postdoctoral fellowships granted by FAPESP (Project Nos. 2018/ 17504-5, 2019/26852-0, and 2015/13345-1-PD, respectively). LP is grateful for a CNPq DTI-A fellowship (CNPq 380405/2020-2). RA is grateful for a doctoral fellowship from FAPESP (Project No. 2019/24553-5).

\section{ACKNOWLEDGMENTS}

We would like to acknowledge the late Geoffrey Burnstock for his seminal contributions to the field of purinergic signaling and the community of purinergic researchers.

attenuates contralateral rotations in a rat model of Parkinsonism through a combined control of synaptotoxicity, neurotoxicity and gliosis. Neuropharmacology 81, 142-152. doi:10.1016/j.neuropharm.2014.01.045

Crabbé, M., Van Der Perren, A., Bollaerts, I., Kounelis, S., Baekelandt, V., Bormans, G., et al. (2019). Increased P2X7 receptor binding is associated with neuroinflammation in acute but not chronic rodent models for Parkinson's disease. Front. Neurosci. 13, 799. doi:10.3389/fnins.2019.00799

Delarasse, C., Auger, R., Gonnord, P., Fontaine, B., and Kanellopoulos, J. M. (2011). The purinergic receptor P2X7 triggers $\alpha$-secretase-dependent processing of the amyloid precursor protein. J. Biol. Chem. 286, 2596. doi:10.1074/jbc.M110. 200618

Deterding, R. R., Lavange, L. M., Engels, J. M., Mathews, D. W., Coquillette, S. J., Brody, A. S., et al. (2007). Phase 2 randomized safety and efficacy trial of nebulized denufosol tetrasodium in cystic fibrosis. Am. J. Respir. Crit. Care Med. 176, 362-369. doi:10.1164/rccm.200608-1238OC

Diaz-Hernandez, J. I., Gomez-Villafuertes, R., León-Otegui, M., Hontecillas-Prieto, L., del Puerto, A., Trejo, J. L., et al. (2012). In vivo P2X7 inhibition reduces amyloid plaques in Alzheimer's disease through GSK3 $\beta$ and secretases. Neurobiol. Aging 33, 1816-1828. doi:10.1016/j.neurobiolaging.2011.09.040

Díaz-Hernández, M., Díez-Zaera, M., Sánchez-Nogueiro, J., Gómez-Villafuertes, R., Canals, J. M., Alberch, J., et al. (2009). Altered P2X7-receptor level and function in mouse models of Huntington's disease and therapeutic efficacy of antagonist administration. FASEB J. 23, 1893-1906. doi:10.1096/fj.08-122275

Dobolyi, A., Juhasz, G., Kovacs, Z., and Kardos, J. (2011). Uridine function in the central nervous system. CTMC 11, 1058-1067. doi:10.2174/ 156802611795347618

Doğan, E., Aygün, H., Arslan, G., Rzayev, E., Avcı, B., Ayyıldız, M., et al. (2020). The role of NMDA receptors in the effect of purinergic P2X7 receptor on spontaneous seizure activity in WAG/rij rats with genetic absence epilepsy. Front. Neurosci. 14, 414. doi:10.3389/fnins.2020.00414

Engel, T., Alves, M., Sheedy, C., and Henshall, D. C. (2016). ATPergic signalling during seizures and epilepsy. Neuropharmacology 104, 140-153. doi:10.1016/j. neuropharm.2015.11.001

Engel, T., Jimenez-Pacheco, A., Miras-Portugal, M. T., Diaz-Hernandez, M., and Henshall, D. C. (2012). P2X7 receptor in epilepsy; role in pathophysiology and potential targeting for seizure control. Int. J. Physiol. Pathophysiol. Pharmacol. 4, 174-187.

Ferrazoli, E. G., de Souza, H. D. N., Nascimento, I. C., Oliveira-Giacomelli, Á., Schwindt, T. T., Britto, L. R., et al. (2017). Brilliant Blue G, but not fenofibrate, treatment reverts hemiparkinsonian behavior and restores dopamine levels in an animal model of Parkinson's disease. Cel Transpl. 26, 669-677. doi:10.3727/ 096368917 X695227

Fonteles, A. A., Neves, J. C. S., Menezes, A. P. F., Pereira, J. F., Silva, A. T. A., Cunha, R. A., et al. (2020). ATP signaling controlling dyskinesia through P2X7 receptors. Front. Mol. Neurosci. 13, 111. doi:10.3389/fnmol.2020.00111

Franke, H., and Illes, P. (2006). Involvement of P2 receptors in the growth and survival of neurons in the CNS. Pharmacol. Ther. 109, 297-324. doi:10.1016/j. pharmthera.2005.06.002

Glaser, T., Andrejew, R., Oliveira-Giacomelli, Á., Ribeiro, D. E., Bonfim Marques, L., Ye, Q., et al. (2020a). Purinergic receptors in basal ganglia diseases: shared 
molecular mechanisms between Huntington's and Parkinson's disease. Neurosci. Bull. 36, 1299-1314. doi:10.1007/s12264-020-00582-8

Glaser, T., de Oliveira, S. L. B., Cheffer, A., Beco, R., Martins, P., Fornazari, M., et al. (2014). Modulation of mouse embryonic stem cell proliferation and neural differentiation by the P2X7 receptor. PLoS One 9, e96281. doi:10.1371/journal. pone. 0096281

Glaser, T., Shimojo, H., Ribeiro, D. E., Martins, P. P. L., Beco, R. P., Kosinski, M., et al. (2020b). ATP and spontaneous calcium oscillations control neural stem cell fate determination in Huntington's disease: a novel approach for cell clock research. Mol. Psychiatry, 1-18. doi:10.1038/s41380-020-0717-5

Gu, B. J., Zhang, W., Worthington, R. A., Sluyter, R., Dao-Ung, P., Petrou, S., et al. (2001). A glu-496 to ala polymorphism leads to loss of function of the human P2X7 receptor. J. Biol. Chem. 276, 11135-11142. doi:10.1074/jbc.M010353200

Helmstaedter, C. (2013). The impact of epilepsy on cognitive function. J. Neurol. Neurosurg. Psychiatry 84, e1. doi:10.1136/jnnp-2013-306103.14

Heneka, M. T., O'Banion, M. K., Terwel, D., and Kummer, M. P. (2010). Neuroinflammatory processes in Alzheimer's disease. J. Neural Transm. 117, 919-947. doi:10.1007/s00702-010-0438-z

Homolya, L., Watt, W. C., Lazarowski, E. R., Koller, B. H., and Boucher, R. C. (1999). Nucleotide-regulated calcium signaling in lung fibroblasts and epithelial cells from normal and P2Y2 receptor $(-/-)$ mice. J. Biol. Chem. 274, 26454-26460. doi:10.1074/jbc.274.37.26454

Hong, S., Xin, Y., JiaWen, W., ShuQin, Z., GuiLian, Z., HaiQin, W., et al. (2020). The $\mathrm{P} 2 \mathrm{X} 7$ receptor in activated microglia promotes depression- and anxietylike behaviors in lithium -pilocarpine induced epileptic rats. Neurochem. Int. 138, 104773. doi:10.1016/j.neuint.2020.104773

Kim, H. J., Ajit, D., Peterson, T. S., Wang, Y., Camden, J. M., Gibson Wood, W., et al. (2012). Nucleotides released from A $\beta 1$-42-treated microglial cells increase cell migration and $\mathrm{A} \beta 1-42$ uptake through $\mathrm{P} 2 \mathrm{Y} 2$ receptor activation. J. Neurochem. 121, 228-238. doi:10.1111/j.1471-4159.2012.07700.x

Kong, Q., Peterson, T. S., Baker, O., Stanley, E., Camden, J., Seye, C. I., et al. (2009). Interleukin-1 $\beta$ enhances nucleotide-induced and $\alpha$-secretase-dependent amyloid precursor protein processing in rat primary cortical neurons via up-regulation of the P2Y2receptor. J. Neurochem. 109, 1300. doi:10.1111/j. 1471-4159.2009.06048.x

Kumar, S., Mishra, A., and Krishnamurthy, S. (2017). Purinergic antagonism prevents mitochondrial dysfunction and behavioral deficits associated with dopaminergic toxicity induced by 6-OHDA in rats. Neurochem. Res. 42, 3414-3430. doi:10.1007/s11064-017-2383-9

Lai, M. K. P., Tan, M. G. K., Kirvell, S., Hobbs, C., Lee, J., Esiri, M. M., et al. (2008). Selective loss of P2Y2 nucleotide receptor immunoreactivity is associated with Alzheimer's disease neuropathology. J. Neural Transm. 115, 1165. doi:10.1007/ s00702-008-0067-y

Lau, O. C., Samarawickrama, C., and Skalicky, S. E. (2014). P2Y2 receptor agonists for the treatment of dry eye disease: a review. Clin. Ophthalmol. 8, 327-334. doi:10.2147/OPTH.S39699

Lee, H. G., Won, S. M., Gwag, B. J., and Lee, Y. B. (2011). Microglial P2X7receptor expression is accompanied by neuronal damage in the cerebral cortex of the APPswe/PS1dE9 mouse model of Alzheimer's disease. Exp. Mol. Med. 43, 7-14. doi:10.3858/emm.2011.43.1.001

Liu, H., Han, X., Li, Y., Zou, H., and Xie, A. (2013). Association of P2X7 receptor gene polymorphisms with sporadic Parkinson's disease in a Han Chinese population. Neurosci. Lett. 546, 42-45. doi:10.1016/j.neulet.2013.04.049

Marcellino, D., Suárez-Boomgaard, D., Sánchez-Reina, M. D., Aguirre, J. A., Yoshitake, T., Yoshitake, S., et al. (2010). On the role of P2X7 receptors in dopamine nerve cell degeneration in a rat model of Parkinson's disease: studies with the P2X7 receptor antagonist A-438079. J. Neural Transm. 117, 681-687. doi:10.1007/s00702-010-0400-0

Martin, E., Amar, M., Dalle, C., Youssef, I., Boucher, C., Le Duigou, C., et al. (2019). New role of P2X7 receptor in an Alzheimer's disease mouse model. Mol. Psychiatry 24, 108-125. doi:10.1038/s41380-018-0108-3

McLarnon, J. G., Ryu, J. K., Walker, D. G., and Choi, H. B. (2006). Upregulated expression of purinergic P2X7Receptor in Alzheimer disease and amyloid- $\beta$ peptide-treated microglia and in peptide-injected rat Hippocampus. J. Neuropathol. Exp. Neurol. 65, 1090-1097. doi:10.1097/01.jnen.0000240470. 97295.d3

Morgan, J., Alves, M., Conte, G., Menéndez-Méndez, A., de Diego-Garcia, L., de Leo, G., et al. (2020). Characterization of the expression of the ATP-gated P2X7 receptor following status epilepticus and during epilepsy using a P2X7-EGFP reporter mouse. Neurosci. Bull. 36, 1242-1258. doi:10.1007/s12264-02000573-9

Noebels, J. (2011). A perfect storm: converging paths of epilepsy and Alzheimer's dementia intersect in the hippocampal formation. Epilepsia 52, 39-46. doi:10. $1111 / j .1528-1167.2010 .02909 . x$

Oliveira, Á., Illes, P., and Ulrich, H. (2016). Purinergic receptors in embryonic and adult neurogenesis. Neuropharmacology 104, 272-281. doi:10.1016/j. neuropharm.2015.10.008

Oliveira-Giacomelli, Á., Albino, C. M., Nóbrega de Souza, H. D., Corrêa-Velloso, J., de Jesus Santos, A. P., Baranova, J., et al. (2019). P2Y6 and P2X7 receptor antagonism exerts neuroprotective/neuroregenerative effects in an animal model of Parkinson's disease. Front. Cel. Neurosci. 13, 476. doi:10.3389/ fncel.2019.00476

Oliveira-Giacomelli, Á., Naaldijk, Y., Sardá-Arroyo, L., Gonçalves, M. C. B., Corrêa-Velloso, J., Pillat, M. M., et al. (2018). Purinergic receptors in neurological diseases with motor symptoms: targets for therapy. Front. Pharmacol. 9, 325. doi:10.3389/fphar.2018.00325

Parvathenani, L. K., Tertyshnikova, S., Greco, C. R., Roberts, S. B., Robertson, B., and Posmantur, R. (2003). P2X7 mediates superoxide production in primary microglia and is up-regulated in a transgenic mouse model of Alzheimer's disease. J. Biol. Chem. 278, 13309. doi:10.1074/jbc.M209478200

Peterson, T. S., Thebeau, C. N., Ajit, D., Camden, J. M., Woods, L. T., Wood, W. G., et al. (2013). Up-regulation and activation of the P2Y2 nucleotide receptor mediate neurite extension in IL-1 $\beta$-treated mouse primary cortical neurons. J. Neurochem. 125, 885-896. doi:10.1111/jnc.12252

Resende, R. R., Britto, L. R. G., and Ulrich, H. (2008). Pharmacological properties of purinergic receptors and their effects on proliferation and induction of neuronal differentiation of P19 embryonal carcinoma cells. Int. J. Dev. Neurosci. 26, 763-777. doi:10.1016/j.ijdevneu.2008.07.008

Ribeiro, D. E., Oliveira-Giacomelli, Á., Glaser, T., Arnaud-Sampaio, V. F., Andrejew, R., Dieckmann, L., et al. (2020). Hyperactivation of P2X7 receptors as a culprit of COVID-19 neuropathology. Mol. Psychiatry 1, 1-16. doi:10.1038/s41380-020-00965-3

Ryu, J. K., and McLarnon, J. G. (2008). Block of purinergic P2X7 receptor is neuroprotective in an animal model of Alzheimer's disease. Neuroreport 19, 1715. doi:10.1097/WNR.0b013e3283179333

Sáez-Orellana, F., Godoy, P. A., Bastidas, C. Y., Silva-Grecchi, T., Guzmán, L., Aguayo, L. G., et al. (2016). ATP leakage induces P2XR activation and contributes to acute synaptic excitotoxicity induced by soluble oligomers of $\beta$-amyloid peptide in hippocampal neurons. Neuropharmacology 100, 116-123. doi:10.1016/j.neuropharm.2015.04.005

Sanz, J. M., Chiozzi, P., Ferrari, D., Colaianna, M., Idzko, M., Falzoni, S., et al. (2009). Activation of microglia by amyloid $\beta$ requires P2X7 receptor expression. J. Immunol. 182, 4378-4385. doi:10.4049/jimmunol.0803612

Song, P., Hu, J., Liu, X., and Deng, X. (2019). Increased expression of the P2X7 receptor in temporal lobe epilepsy: animal models and clinical evidence. Mol. Med. Rep. 19, 5433-5439. doi:10.3892/mmr.2019.10202

Soo, Y. K., Ju, H. M., Hwan, G. L., Seung, U. K., and Yong, B. L. (2007). ATP released from $\beta$-amyloid-stimulated microglia induces reactive oxygen species production in an autocrine fashion. Exp. Mol. Med. 39 (6), 820-827. doi:10. 1038/emm.2007.89

Sperlágh, B., and Illes, P. (2014). P2X7 receptor: an emerging target in central nervous system diseases. Trends Pharmacol. Sci. 35, 537-547. doi:10.1016/j.tips. 2014.08.002

Tönnies, E., and Trushina, E. (2017). Oxidative stress, synaptic dysfunction, and Alzheimer's disease. Jad 57, 1105-1121. doi:10.3233/JAD-161088

Ulrich, H., Abbracchio, M. P., and Burnstock, G. (2012). Extrinsic purinergic regulation of neural stem/progenitor cells: implications for CNS development and repair. Stem Cel. Rev. Rep. 8, 755-767. doi:10.1007/ s12015-012-9372-9

Vermunt, L., Sikkes, S. A. M., van den Hout, A., Handels, R., Bos, I., van der Flier, W. M., et al. (2019). Duration of preclinical, prodromal, and dementia stages of Alzheimer's disease in relation to age, sex, and APOE genotype. Alzheimer's Demen. 15, 888-898. doi:10.1016/j.jalz.2019.04.001

Weisman, G. A., Ajit, D., Garrad, R., Peterson, T. S., Woods, L. T., Thebeau, C., et al. (2012a). Neuroprotective roles of the P2Y2 receptor. Purinergic Signal. 8, 559-578. doi:10.1007/s11302-012-9307-6 
Weisman, G. A., Camden, J. M., Peterson, T. S., Ajit, D., Woods, L. T., and Erb, L. (2012b). P2 receptors for extracellular nucleotides in the central nervous system: role of $\mathrm{P} 2 \mathrm{X} 7$ and $\mathrm{P} 2 \mathrm{Y} 2$ receptor interactions in neuroinflammation. Mol. Neurobiol. 46, 96-113. doi:10.1007/s12035012-8263-Z

Wilkaniec, A., Cieślik, M., Murawska, E., Babiec, L., Gąssowska-Dobrowolska, M., Pałasz, E., et al. (2020). P2X7 receptor is involved in mitochondrial dysfunction induced by extracellular alpha synuclein in neuroblastoma SH-SY5Y cells. IJMS 21, 3959. doi:10.3390/ijms21113959

Wilkaniec, A., Gạssowska, M., Czapski, G. A., Cieślik, M., Sulkowski, G., and Adamczyk, A. (2017). P2X7 receptor-pannexin 1 interaction mediates extracellular alpha-synuclein-induced ATP release in neuroblastoma SH-SY5Y cells. Purinergic Signal. 13, 347-361. doi:10.1007/s11302-0179567-2

Yuahasi, K. K., Demasi, M. A., Tamajusuku, A. S. K., Lenz, G., Sogayar, M. C., Fornazari, M., et al. (2012). Regulation of neurogenesis and gliogenesis of retinoic acid-induced P19 embryonal carcinoma cells by P2X2 and P2X7 receptors studied by RNA interference. Int. J. Dev. Neurosci. 30, 91-97. doi:10.1016/j.ijdevneu.2011.12.010

Zeng, X., Chen, L., Zhou, L., Luo, W., Hu, K., and Ouyang, D. (2017). Expression and spatial distribution of $\mathrm{P} 2 \mathrm{X} 7$ receptor in pilocarpine-induced epileptic rat hippocampus. J. Cent. South Univ. 42, 997-1002. doi:10.11817/j.issn.1672-7347.2017.09.001

Conflict of Interest: The authors declare that the research was conducted in the absence of any commercial or financial relationships that could be construed as a potential conflict of interest.

Copyright $(02021$ Glaser, Oliveira-Giacomelli, Petiz, Ribeiro, Andrejew and Ulrich This is an open-access article distributed under the terms of the Creative Commons Attribution License (CC BY). The use, distribution or reproduction in other forums is permitted, provided the original author(s) and the copyright owner(s) are credited and that the original publication in this journal is cited, in accordance with accepted academic practice. No use, distribution or reproduction is permitted which does not comply with these terms. 